\title{
Work-related injuries among child street-laborers in Latin America: prevalence and predictors
}

\author{
Angela Maria Pinzon-Rondon, ${ }^{1}$ Sally A. Koblinsky, ${ }^{1}$ Sandra L. Hofferth, ${ }^{1}$ \\ Carlos E. Pinzon-Florez, ${ }^{2}$ and Leonardo Briceno ${ }^{3}$
}

Suggested citation Pinzon-Rondon AM, Koblinsky SA, Hofferth SL, Pinzon-Florez CE, Briceno L. Work-related injuries among child street-laborers in Latin America: prevalence and predictors. Rev Panam Salud Publica. 2009;26(3):235-43.

ABSTRACT Objectives. To determine the prevalence and nature of occupational injuries among children working in the streets of four major cities in Latin America, as well as to identify factors that predict these work-related injuries.

Methods. This cross-sectional study interviewed 584 children from 5-17 years of age working on the streets of Bogotá, Colombia; Lima, Peru; Quito, Ecuador; and São Paulo, Brazil. Descriptive analyses and multivariate logistic regressions were conducted, with incidence and serious injuries regressed on occupational and sociodemographic variables.

Results. Approximately $39.6 \%$ of the child street-laborers surveyed reported an injury sustained while working in the streets: scratches (19.5\%), cuts/lacerations (16.4\%), burns $(8.6 \%)$, car accidents $(8.9 \%)$, sprains $(4.6 \%)$, and amputations $(0.3 \%)$. Working a high number of daytime hours and performing on the street predicted the greatest risk of injury, even after controlling for sociodemographic factors; specifically, each additional hour of daytime work increased the risk of injury by $1.4 \%$. Child performers had three times the injury rate of children primarily selling products. Boys, older children, and children in Quito were more likely to experience moderate-to-severe injuries, than girls, younger children, and street children in the other study cities.

Conclusions. Interventions are needed to address the substantial risk of injury experienced by children working on the city streets of Latin America.

Key words Child labor; homeless youth; accidents, occupational; Brazil; Colombia; Ecuador; Latin America; Peru.

1 Department of Family Science, University of Maryland, College Park, Maryland, United States of America; and Facultad de Medicina, Universidad del Rosario, Bogotá, Colombia. Send correspondence to: Angela Maria Pinzon-Rondon, 1204 Marie Mount Hall, Department of Family Science, University of Maryland at College Park, College Park, MD 20742, United States; telephone: +01-301405-3672; fax: +01-301-314-9161; email: ampinzon@ umd.edu or ampinzon@urosario.edu.co

2 Instituto Nacional de Cancerología, Bogotá, Colombia.

3 Centro de Asesoría y Consultoría en Salud Ocupacional, Universidad del Rosario, Bogotá, Colombia.
According to the International Labor Organization (ILO), approximately 218 million of the world's children 5-17 years of age are in the workforce, and most of them are laboring in hazardous occupations (1). International standards dictate that children less than 15 years of age not be allowed to work (2) and that those less than 18 years of age not work in dangerous occupations (3). Unfortunately, current cultural and socioeconomic circum- stances in many areas of the world have made this standard the ideal, rather than the reality. Poverty, parental unemployment, beliefs about the advantages of child work, lack of schools, socioeconomic inequalities, discrimination, wars and conflicts, and the absence of policies prohibiting child labor have all contributed to child employment (4).

Although there are street children working in most of the world's cities, the 
majority labor in the developing world (4). These children, like most street laborers, do not benefit from even the most basic labor regulations and tolerate low wages, long hours, night labor, no health care coverage, and a variety of occupational risks (5). Some of these children live and work in the streets, while others leave their homes to engage in daily street work (6). Most child laborers work in the informal sector or unofficial economy (1).

The streets of many Latin American cities are full of child laborers; they can be seen at the corners, traffic lights, bus stops, and parking lots. The ILO has recognized street labor as one of the most hazardous and exploitative forms of child labor, citing it as a problem in Bolivia, Chile, Ecuador, El Salvador, Nicaragua, Panama, Paraguay, and throughout Latin America (7). Given the high incidence of child street labor in this geographic area and its potential dangers, it is important to study the nature and prevalence of occupational injuries among this population of workers and to identify factors that may increase the risk of injury.

Previous research reveals that children throughout the world are more susceptible to work-related injuries than adults, even after controlling for occupational variables (8-10). Children's higher risk level, relative to adults, has been attributed to their less mature biological systems, greater vulnerability to toxic exposure, lower levels of strength, increased energy needs, lower resistance to temperature change, and lower ability to manage tools. Children's greater risk of work injuries may also be influenced by their disproportionate exposure to environmental toxins. Children eat, breathe, and drink more water per unit of corporal weight than adults (11). Finally, children's premature assumption of adult responsibilities may enhance both physical and psychological risks of injury. Child workers may consider injuries "part of the job" over which they have little or no control. Their insecurity and desire to appear mature reduces the likelihood that they will complain about work conditions (12).

\section{Definitions, prevalence, and predictors}

The ILO has defined occupational injury as "death, or any personal injury or disease resulting from an occupational accident;" an occupational accident is defined as an "occurrence arising out of or in the course of work" (13). However, the literature reveals no single way to classify occupational injuries, with researchers measuring a range of minor, moderate, and severe injuries that include scratches, strains, sprains, fractures, cuts/lacerations, burns, bruises, amputations, and paralysis (14-16).

The reported incidence of child occupational injury varies enormously as a function of the research study and country in which it was conducted. Estimates of work injuries suffered by individuals less than 20 years of age include: $6.4 \%$ in Salvador, Brazil, from a household survey (17); $3.3 \%$ in Botucatu, Brazil, from a household survey (18); $4.5 \%$ in the United States of America (US) from emergency room records (19); $9.0 \%$ in the US from occupational compensation registers (20); and $17.0 \%$ in the US from a school-based survey (21). Research also suggests that a large percentage of child occupational injuries are underreported (22).

Previous studies have also examined factors associated with a higher prevalence of child occupational injuries. In one study of 319 adolescents 16-19 years of age in Erie County, New York, Frone found that higher injury levels were associated with being male, negative affectivity, longer job tenure, exposure to physical hazards, excessive workloads, job boredom, poor physical health, and on-the-job substance use (15). Other studies of US children less than 17 years have linked greater occupational injuries to male gender $(20,23)$, being a member of a racial minority group (24-26), working more hours $(23,27)$, and working late night hours (23). Studies exploring the relationship between child age and work injuries have had mixed results, with some showing more injuries in the younger years (17, $28,29)$ and some showing a higher incidence among older child workers $(30,31)$. Children's occupational injuries have also been associated with differences in tasks, amount of workplace hazard exposure, and sociodemographic variables. For example, among child agricultural workers in the US, children who use machinery have the highest injury rates $(32,33)$. In Canada, socioeconomic variables have been associated with higher rates of occupational injuries among youth (34).

\section{Risk of injury among working street-children}

To date, few empirical studies have examined the prevalence or nature of occupational injuries among children working on the streets of cities in Latin America. However, data indicate that the number of children working on the streets of these urban areas is large and growing (35). This situation is of particular concern to public health workers, educators, and human service personnel given the potential dangers of street work. Children in Latin America who engage in street labor may be exposed to physical risk factors, such as solar radiation, dust, noise, and weather changes (11); biological risk factors, such as infectious diseases and contact with unhealthy street animals (11); chemical risk factors, such as environmental pollutants and engine exhaust (36-38); ergonomic risk factors, such as heavy loads, long hours of standing, repetitive movements, and voice overuse (11); and psychosocial risk factors, such as violence, sexual abuse, prosecution by authorities, and exposure to drug dealers and other criminal elements $(39,40)$. Children's risk of injury may also be tied to the nature of their work, with street jobs found to vary by age (41). One study found that street children less than 5 years of age usually beg for money; children 5-10 years of age often sell items, perform, or clean cars; and adolescents generally sell merchandise (42).

The present study sought to expand existing literature on occupational injuries among children by focusing on young street laborers in a few major cities in Latin America. In addition to assessing the nature and prevalence of children's occupational injuries, the study is unique in examining the range of injury predictors, namely occupation (type, daytime hours, nighttime hours); individual (gender, age, race); social (school attendance, health care coverage, family/housing status); and geography (city).

\section{MATERIALS AND METHODS}

\section{Participants and procedure}

This cross-sectional study utilized a dataset from the unpublished project, "Trabajo infantil en las calles de ciudades Latinoamericanas." 4 The data were collected through interviews with 584 children working on the streets of Bogotá,

\footnotetext{
4 Directed by Angela M. Pinzon-Rondon and sponsored by the Universidad del Rosario, Bogotá, Colombia, 2005. Available from the Oficina de Investigaciones, Universidad del Rosario.
} 
Colombia; Lima, Peru; Quito, Ecuador; and São Paulo, Brazil, from mid-April 2005 to mid-June 2005. These four cities are among the largest in their countries, and their combined population is half the population of Latin America. In terms of per-capita income, these four countries are below the mean and close to the median of all Latin American nations (43).

Participants were children 5-17 years of age working on the street on a school day, within a 40-block radius of each city's main government building. Using a convenience sampling technique, interviewers asked each child with these criteria to complete an oral interview. Interviewers were residents of the target city and held at least a bachelor's degree in public health or social science. All had completed a one-day training seminar that required demonstrating mastery of the study protocol and questionnaire.

The child or their guardian provided informed consent for the 15-minute interview and received a sandwich and a drink. Participation was voluntary and no identifying information was collected. The protocol followed the international conventions for research on human subjects and was approved by the Committee on Research Ethics of the School of Health Sciences of the University of El Rosario in Bogotá, Colombia. A response rate above $95 \%$ was obtained in all cities.

\section{Survey instrument}

The study's 50-item questionnaire was semistructured and administered orally by an interviewer. Many of the questions came from previous studies of Latin American street children conducted by the first author $(6,42,44)$. Colleagues in each target city modified the questionnaire to fit the local language. While the survey was originally developed in Spanish, it was translated into Portuguese (for Brazilian children) using forward and backward translation. The instrument was piloted with 50 street children in Bogotá (in a location different from the targeted study area) and found to be reliable; minor revisions were made in the phrasing of some questions.

Questionnaire items addressed sociodemographic characteristics, the child's occupation, and the nature and severity of occupational injuries. Sociodemographic items included individual factors, such as gender, age in years, minority status (black/native versus white/mestizo), current school attendance (yes/no), residential status (living/not living in the streets), displaced status (yes/no), health care coverage (yes/no), and city of residence. Displaced children were those who came to the city from the countryside as a result of forced migration, generally caused by armed conflict or extreme poverty. Children defined as having health care coverage were those with access to health care through a health insurance card or a support system that could provide medical care.

Questionnaire items addressing the child's street occupation included: hours of daytime work per week, hours of nighttime work per week, and primary occupation. The latter category included: selling, defined as selling products (e.g., candy, fruits, lottery tickets, flowers, phone batteries); begging, defined as asking for money without offering anything in exchange; cleaning or guarding cars, defined as washing windshields and car lights or protecting cars from theft; and performing, defined as carrying out acts (e.g., gymnastics, juggling balls or fire sticks) in the streets.

There were seven items assessing occupational injuries. The first set asked children whether or not they had suffered six specific injuries (and a category of "other") while working on the streets. When children responded that they had experienced a particular injury, the interviewer probed them to provide details of its occurrence. Categories included: scratches, sprains, cuts/lacerations, burns, car accidents, and amputations. Injuries were only recorded when they were significant enough to prevent the child from continuing work on the day of injury. These injuries were then classified for subsequent analyses as being either "mild" (scratches, sprains, cuts/lacerations) or "moderate-to-severe" (burns, car accidents, amputations).

\section{Data analyses}

Descriptive statistics were calculated to describe the sample in terms of sociodemographic factors, occupational factors, and occupational injuries. These statistics included means, standard deviations, ranges, and percentages, as appropriate. In $4.3 \%$ of the sample ( 25 cases), data were missing for the number of hours worked; in these cases, the mean value was used. Bivariate correlations were then conducted to examine the rela- tionships between the independent variables (sociodemographic and occupational factors) and occupational injuries for the total sample and for a subsample of those who experienced injuries.

Binary logistic regressions were conducted to examine predictors for any occupational injury and for moderate-tosevere injury. First, the occupational injury was regressed on the occupational variables, "daytime work hours," "nighttime work hours," "begging," "cleaning/ guarding cars," "performing," and other occupations; the occupation "selling" was the omitted category. Second, the demographic variables, "age," "gender," and "minority status," were added to the model. Third, characteristics of the child's social environment, "schooling," "residential status," "displacement status," and "city," were added. The primary focus of the study was on the occupational variables; however, there was also an interest in how the child's demographic traits and social environment affect and, perhaps, explain these associations. A second set of binary logistic regressions applied moderate-to-severe occupational injury on the various sets of occupational and sociodemographic variables using the same procedure described above. A $P$ value of $<0.05$ was considered significant for all statistical tests. The analyses were performed using Statistical Package for the Social Sciences version 14.0 (SPSS Inc., Chicago, Illinois, United States).

\section{RESULTS}

Table 1 presents descriptive statistics for the whole population and the subset of children who reported injuries. Of the 584 children in the dataset, $34.4 \%$ were from Lima (Peru); $37.1 \%$ from Bogotá (Colombia); $17.8 \%$ from São Paulo; and $16.1 \%$ from Quito (Ecuador). Approximately two-thirds of the children $(68.3 \%)$ were boys, and one-third (31.7\%), girls; $15.2 \%$ were minorities (native/black). The age of the children ranged from 5-17 years, with a mean of 11.8 years. Children less than 12 years of age were more likely to be displaced, to have health care coverage, to work as beggars, to attend school, and to live in Bogotá or São Paulo. Older children were more likely to work in other occupations and to live in Lima. Regarding residential and school status, approximately two-thirds $(64.9 \%)$ were displaced from their area of 
TABLE 1. Characteristics of a total sample of 584 child street-laborers and a sample of 231 injured in Latin America, 2005

\begin{tabular}{|c|c|c|c|c|c|c|c|c|}
\hline \multirow[b]{2}{*}{ Variable } & \multicolumn{4}{|c|}{ Total sample, $n=584$} & \multicolumn{4}{|c|}{ Injured sample, $n=231$} \\
\hline & Minimum & Maximum & Mean & S.D. ${ }^{a}$ & Minimum & Maximum & Mean & S.D. ${ }^{2}$ \\
\hline Occupational injury (1 = yes) & 0 & 1 & 0.396 & 0.49 & 1 & 1 & 1.000 & 0.00 \\
\hline Moderate to severe injury $(1=$ yes $)$ & 0 & 1 & 0.164 & 0.37 & 0 & 1 & 0.416 & 0.49 \\
\hline \multicolumn{9}{|l|}{ Injury } \\
\hline Scratch & 0 & 1 & 0.195 & 0.40 & 0 & 1 & 0.494 & 0.50 \\
\hline Cut/Laceration & 0 & 1 & 0.164 & 0.37 & 0 & 1 & 0.416 & 0.49 \\
\hline Sprain & 0 & 1 & 0.046 & 0.21 & 0 & 1 & 0.117 & 0.32 \\
\hline Burn & 0 & 1 & 0.086 & 0.28 & 0 & 1 & 0.216 & 0.41 \\
\hline Hit by car & 0 & 1 & 0.089 & 0.29 & 0 & 1 & 0.225 & 0.42 \\
\hline Amputation & 0 & 1 & 0.003 & 0.06 & 0 & 1 & 0.009 & 0.09 \\
\hline Hours of daytime work/week & 0 & 102 & 38.700 & 24.24 & 0 & 91 & 44.935 & 23.57 \\
\hline Hours of nighttime work/week & 0 & 60 & 7.293 & 9.87 & 0 & 60 & 7.710 & 10.62 \\
\hline \multicolumn{9}{|l|}{ Occupation } \\
\hline Selling (1 = yes) & 0 & 1 & 0.527 & 0.50 & 0 & 1 & 0.511 & 0.50 \\
\hline Cleaning/Guarding cars ( 1 = yes) & 0 & 1 & 0.108 & 0.31 & 0 & 1 & 0.104 & 0.31 \\
\hline Begging $(1=$ yes $)$ & 0 & 1 & 0.101 & 0.30 & 0 & 1 & 0.078 & 0.27 \\
\hline Performing (1=yes) & 0 & 1 & 0.033 & 0.18 & 0 & 1 & 0.052 & 0.22 \\
\hline Other (1 = yes) & 0 & 1 & 0.231 & 0.42 & 0 & 1 & 0.255 & 0.44 \\
\hline Age (years) & 5 & 17 & 11.849 & 3.20 & 5 & 17 & 12.411 & 3.27 \\
\hline Gender (1 = girls) & 0 & 1 & 0.317 & 0.47 & 0 & 1 & 0.268 & 0.44 \\
\hline Minorities (1 = yes) & 0 & 1 & 0.152 & 0.36 & 0 & 1 & 0.130 & 0.34 \\
\hline Schooling (1 = yes) & 0 & 1 & 0.659 & 0.47 & 0 & 1 & 0.602 & 0.49 \\
\hline Lives on the street $(1=$ yes $)$ & 0 & 1 & 0.070 & 0.26 & 0 & 1 & 0.091 & 0.29 \\
\hline Displaced child (1 = yes) & 0 & 1 & 0.649 & 0.48 & 0 & 1 & 0.589 & 0.49 \\
\hline Health care coverage $(1=$ yes $)$ & 0 & 1 & 0.370 & 0.48 & 0 & 1 & 0.312 & 0.46 \\
\hline Bogotá & 0 & 1 & 0.317 & 0.47 & 0 & 1 & 0.299 & 0.46 \\
\hline Lima & 0 & 1 & 0.344 & 0.48 & 0 & 1 & 0.355 & 0.48 \\
\hline Quito & 0 & 1 & 0.161 & 0.37 & 0 & 1 & 0.208 & 0.41 \\
\hline São Paulo & 0 & 1 & 0.178 & 0.38 & 0 & 1 & 0.139 & 0.35 \\
\hline
\end{tabular}

a Standard deviation.

TABLE 2. Bivariate correlations of occupational injury and moderate-to-severe injury with occupational and sociodemographic factors in a sample of 584 child street-laborers in Latin America, 2005

\begin{tabular}{lcc}
\hline Independent variable & $\begin{array}{c}\text { Occupational injury } \\
(0=\text { No, } 1=\text { Yes }) \\
(n=584)\end{array}$ & $\begin{array}{c}\text { Moderate-to-severe injury } \\
\left(0=\begin{array}{c}\text { No, } 1=\text { Yes }) \\
(n=231)\end{array}\right.\end{array}$ \\
\hline Hours of daytime work & $0.21^{\mathrm{a}}$ & 0.08 \\
Hours of nighttime work & 0.03 & 0.03 \\
Occupation & & -0.04 \\
Selling & -0.03 & 0.03 \\
Cleaning/Guarding cars & -0.01 & 0.02 \\
Begging & -0.06 & -0.08 \\
Performing & $0.09^{\mathrm{b}}$ & 0.05 \\
Other & 0.05 & $0.12^{\mathrm{c}}$ \\
Age & $0.14^{\mathrm{a}}$ & $-0.15^{\mathrm{b}}$ \\
Gender $(1=$ girls $)$ & $-0.08^{\mathrm{b}}$ & $0.12^{\mathrm{c}}$ \\
Minorities & -0.05 & -0.03 \\
Schooling & $-0.10^{\mathrm{b}}$ & $0.13^{\mathrm{b}}$ \\
Lives on the street & 0.07 & $-0.19^{\mathrm{d}}$ \\
Displaced child & $-0.10^{\mathrm{b}}$ & -0.02 \\
Health care coverage & $-0.10^{\mathrm{b}}$ & $-0.15^{\mathrm{b}}$ \\
Bogotá & -0.03 & -0.04 \\
Lima & 0.02 & $0.13^{\mathrm{b}}$ \\
Quito & $0.10^{\mathrm{b}}$ & 0.09 \\
São Paulo & $-0.08^{\mathrm{b}}$ & \\
\hline Note: all $P$ values were two-tailed tests. & & \\
a $P<.001$. & & \\
b $P<.05$. & & \\
c $P<.10$. & & \\
d $P<.01$. & & \\
& &
\end{tabular}

origin; $7.0 \%$ were living on the street; and $65.9 \%$ were in school. Only $37.0 \%$ reported any kind of health care coverage.
In terms of primary occupation, more than one-half $(52.7 \%)$ of the children in the sample were selling products; about
1 in 10 was engaged in either begging $(10.1 \%)$ or cleaning/guarding cars $(10.8 \%)$; $3.3 \%$ were street performers; and the remaining $23.1 \%$ were involved in a variety of other occupations (e.g., garbage collection, recycling, shoe shining). Children worked an average of 38.7 hours weekly in the daytime and 7.3 hours weekly at night.

Overall, $39.6 \%$ of the working street children of these cities reported one of the following significant injuries: scratches (19.5\%), cuts/lacerations (16.4\%), burns $(8.6 \%)$, car accidents $(8.9 \%)$, sprains $(4.6 \%)$, and amputations $(0.3 \%)$. Approximately $16.4 \%$ of the children had suffered an injury classified as moderate-to-severe (burns, car accidents, amputations).

Table 2 shows the bivariate correlations between the independent variables and the presence of any occupational injury, and of a moderate-to-severe injury. Hours of daytime work, performing, age, male gender, and Quito residence had a significant positive association with suffering any occupational injury; while school attendance, displaced living status, health care coverage, and São Paulo residence had a significant negative association with these injuries. Thus, children 
who worked more daytime hours per week, performed, were male, older, and resided in Quito had a higher incidence of injury, while those who attended school, were displaced, had social security, and were residents of São Paolo had less risk. When focusing on the subset of moderate-to-severe occupational injuries, male gender, living on the street, and Quito residence had a significant positive association with injury, whereas displaced status and Bogotá residence had a significant negative relationship. Thus, male children living on the streets of Quito were more likely to suffer moderate-to-severe occupational injuries, than those who had been displaced and were residents of Bogotá. There was also a trend for older age and minority status to be linked with a higher incidence of moderate-to-severe injuries.

\section{Predictors of occupational injuries}

Table 3 presents results from the binary logistic regression analyses predicting occurrence of any occupational injury. The occupational factors, "hours of daytime work" and "street performing" were associated with occurrence of occupational injury in Model 1 and remained significant after controlling for gender, age, minority status, schooling, street residence, displacement, social security, and city of residence (Models 2, 3, and 4). Children who spent more daytime hours working on the streets and who performed street acts were at greater risk of injury than those who worked fewer hours and had other occupations. Each additional hour of daytime work increased the risk of injury by 1.4 percent (odds ratio $(\mathrm{OR})=1.01$ in Model 4). Performing as an occupation was associated with a risk of injury three times $(\mathrm{OR}=3.09)$ that of children whose primary occupation was selling products.

The child's age and minority status were also associated with occupational injury (Model 2), remaining significant after controlling for the remaining variables in the model. Each additional year of age was associated with a 6.5 percent increase in risk of injury. Minority group status was linked to a lower risk of injury, approximately one-half that of the majority population $(\mathrm{OR}=0.48)$.

Table 4 presents the binary logistic regression analyses for risk of having a moderate-to-severe injury. As shown in Model 1, none of the occupational variables, including type of occupation and hours of daytime and nighttime work, was associated with a moderate-to-severe injury (Model 1). In Model 2, gender emerged as a significant predictor, with girls having a risk of moderate-to-severe injuries half that of boys $(\mathrm{OR}=0.45$, Model 2). This association remains significant after controlling for other study variables (Models 3 and 4). Model 3 shows a trend for displaced status to be associated with a lower risk of moderateto-severe injuries; however this decreased risk does not remain after controlling for street residence, displaced status, health care coverage, and city of residence in Model 4. The final model also shows trends for older children and those residing in Quito to suffer more severe injuries than younger children or children living in other cities. It is important to note these trends because the sample size for this regression is smaller than that of the full sample, reducing power.

\section{DISCUSSION}

The current study examined the prevalence and predictors of occupational injuries among child street laborers who were 5-17 years of age living in Bogotá, Lima, Quito, and São Paulo. To the best of the authors' knowledge, this investigation is the first to examine a large sample of child street laborers in several na-

TABLE 3. Binary logistic regression models for occurrence of occupational injury among child street-laborers in Latin America, 2005

\begin{tabular}{|c|c|c|c|c|c|c|c|c|c|c|c|c|c|c|c|c|}
\hline \multirow[b]{2}{*}{ Independent variable } & \multicolumn{4}{|c|}{ Model 1} & \multicolumn{4}{|c|}{ Model 2} & \multicolumn{4}{|c|}{ Model 3} & \multicolumn{4}{|c|}{ Model 4} \\
\hline & $\mathrm{B}^{\mathrm{a}}$ & S.E. ${ }^{b}$ & $P^{c}$ & $\mathrm{OR}^{\mathrm{d}}$ & $\mathrm{B}^{\mathrm{a}}$ & S.E. ${ }^{b}$ & $P^{\mathrm{c}}$ & $\mathrm{OR}^{\mathrm{d}}$ & $\mathrm{B}^{\mathrm{a}}$ & S.E. ${ }^{b}$ & $P^{c}$ & $\mathrm{OR}^{\mathrm{d}}$ & $\mathrm{B}^{\mathrm{a}}$ & S.E. ${ }^{b}$ & $P^{\mathrm{c}}$ & $\mathrm{OR}^{\mathrm{d}}$ \\
\hline Constant & -1.18 & 0.19 & $<0.001$ & 0.31 & -1.82 & 0.39 & $<0.001$ & 0.16 & -1.29 & 0.49 & $<0.01$ & 0.28 & -1.29 & 0.53 & $<0.05$ & 0.27 \\
\hline Hours of daytime work & 0.02 & 0.00 & $<0.001$ & 1.02 & 0.02 & 0.00 & $<0.001$ & 1.02 & 0.02 & 0.00 & $<0.001$ & 1.02 & 0.01 & 0.00 & $<0.001$ & 1.01 \\
\hline Hours of nighttime work & 0.00 & 0.01 & & 1.00 & 0.00 & 0.01 & & 1.00 & 0.00 & 0.01 & & 1.00 & 0.01 & 0.01 & & 1.01 \\
\hline \multicolumn{17}{|l|}{ Occupation } \\
\hline Selling ( 1 = yes) & $N A^{e}$ & & & & & & & & & & & & & & & \\
\hline \multicolumn{17}{|l|}{ Cleaning/Guarding cars } \\
\hline$(1=$ yes $)$ & -0.09 & 0.29 & & 0.92 & -0.14 & 0.29 & & 0.87 & -0.26 & 0.31 & & 0.77 & -0.23 & 0.33 & & 0.79 \\
\hline Begging (1 = yes) & -0.60 & 0.32 & $<0.10$ & 0.55 & -0.33 & 0.34 & & 0.72 & -0.49 & 0.35 & & 0.61 & -0.37 & 0.36 & & 0.69 \\
\hline Performing $(1=$ yes $)$ & 1.15 & 0.50 & $<0.05$ & 3.16 & 1.17 & 0.50 & $<0.05$ & 3.23 & 1.19 & 0.50 & $<0.05$ & 3.28 & 1.13 & 0.52 & $<0.05$ & 3.09 \\
\hline Other (1 = yes) & 0.07 & 0.22 & & 1.08 & -0.08 & 0.23 & & 0.92 & -0.12 & 0.23 & & 0.89 & -0.19 & 0.24 & & 0.82 \\
\hline Age & & & & & 0.07 & 0.03 & $<0.05$ & 1.07 & 0.06 & 0.03 & $<0.05$ & 1.06 & 0.06 & 0.03 & $<0.05$ & 1.06 \\
\hline Gender (1 = girl) & & & & & -0.24 & 0.20 & & 0.79 & -0.24 & 0.20 & & 0.79 & -0.21 & 0.20 & & 0.81 \\
\hline Minorities ( 1 = yes) & & & & & -0.46 & 0.26 & $<0.10$ & 0.63 & -0.60 & 0.27 & $<0.05$ & 0.55 & -0.74 & 0.30 & $<0.05$ & 0.48 \\
\hline Schooling (1 = yes) & & & & & & & & & -0.23 & 0.20 & & 0.80 & -0.30 & 0.22 & & 0.74 \\
\hline Lives on the street $(1=$ yes $)$ & & & & & & & & & 0.37 & 0.38 & & 1.45 & 0.51 & 0.40 & & 1.67 \\
\hline Displaced child (1 = yes) & & & & & & & & & -0.28 & 0.21 & & 0.76 & -0.19 & 0.22 & & 0.82 \\
\hline \multicolumn{17}{|l|}{ Health care coverage } \\
\hline$(1$ = yes $)$ & & & & & & & & & & & & & -0.08 & 0.21 & & 0.92 \\
\hline Lima & & & & & & & & & & & & & NA & & & \\
\hline Bogotá & & & & & & & & & & & & & 0.01 & 0.26 & & 1.01 \\
\hline Quito & & & & & & & & & & & & & 0.51 & 0.32 & & 1.67 \\
\hline São Paulo & & & & & & & & & & & & & -0.12 & 0.32 & & 0.88 \\
\hline
\end{tabular}

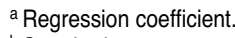

${ }^{b}$ Standard error.

c Two-tailed test.

d Odds ratio.

e Not available.
} 
TABLE 4. Binary logistic regression models for moderate-to-severe occupational injury among child street-laborers in Latin America, 2005

\begin{tabular}{|c|c|c|c|c|c|c|c|c|c|c|c|c|c|c|c|c|}
\hline \multirow[b]{2}{*}{ Independent variable } & \multicolumn{4}{|c|}{ Model 1} & \multicolumn{4}{|c|}{ Model 2} & \multicolumn{4}{|c|}{ Model 3} & \multicolumn{4}{|c|}{ Model 4} \\
\hline & $\mathrm{B}^{\mathrm{a}}$ & S.E. & $P^{c}$ & $\mathrm{OR}^{\mathrm{d}}$ & $\mathrm{B}^{\mathrm{a}}$ & S.E. ${ }^{b}$ & $P^{c}$ & $\mathrm{OR}^{\mathrm{d}}$ & $\mathrm{B}^{\mathrm{a}}$ & S.E. & $P^{c}$ & $\mathrm{OR}^{\mathrm{d}}$ & $\mathrm{B}^{\mathrm{a}}$ & S.E. ${ }^{b}$ & $P^{c}$ & $\mathrm{OR}^{\mathrm{d}}$ \\
\hline Constant & -0.66 & 0.31 & $<0.05$ & 0.52 & -1.28 & 0.64 & $<0.05$ & 0.28 & -0.81 & 0.76 & & 0.45 & -1.18 & 0.88 & & 0.31 \\
\hline Hours of daytime work/week & 0.01 & 0.01 & & 1.01 & 0.00 & 0.01 & & 1.00 & 0.00 & 0.01 & & 1.00 & 0.00 & 0.01 & & 1.00 \\
\hline $\begin{array}{l}\text { Hours of nighttime work/week } \\
\text { Occupation }\end{array}$ & 0.01 & 0.01 & & 1.01 & 0.01 & 0.01 & & 1.01 & 0.01 & 0.01 & & 1.01 & 0.01 & 0.02 & & 1.01 \\
\hline $\begin{array}{l}\text { Selling }(1=\text { yes }) \\
\text { Cleaning/Guarding cars }\end{array}$ & NA & & & & & & & & & & & & & & & \\
\hline$(1=$ yes $)$ & 0.22 & 0.45 & & 1.24 & 0.22 & 0.47 & & 1.25 & -0.01 & 0.51 & & 0.99 & 0.03 & 0.55 & & 1.03 \\
\hline Begging $(1=$ yes $)$ & 0.11 & 0.52 & & 1.11 & 0.17 & 0.57 & & 1.19 & -0.03 & 0.63 & & 0.97 & -0.05 & 0.66 & & 0.95 \\
\hline Performing ( $1=$ yes) & -0.67 & 0.70 & & 0.51 & -0.89 & 0.73 & & 0.41 & -0.84 & 0.74 & & 0.43 & -0.60 & 0.78 & & 0.55 \\
\hline Other (1 = yes) & 0.18 & 0.33 & & 1.20 & -0.01 & 0.35 & & 0.99 & -0.17 & 0.37 & & 0.84 & -0.33 & 0.39 & & 0.72 \\
\hline Age (years) & & & & & 0.07 & 0.05 & & 1.07 & 0.07 & 0.05 & & 1.07 & 0.09 & 0.05 & $<0.10$ & 1.10 \\
\hline Gender (1 = girl) & & & & & -0.80 & 0.34 & $<0.05$ & 0.45 & -0.77 & 0.34 & $<0.05$ & 0.46 & -0.71 & 0.35 & $<0.05$ & 0.49 \\
\hline Minorities ( $1=$ yes) & & & & & 0.70 & 0.44 & & 2.02 & 0.46 & 0.46 & & 1.58 & -0.10 & 0.52 & & 0.90 \\
\hline Schooling ( 1 = yes) & & & & & & & & & 0.02 & 0.32 & & 1.02 & -0.22 & 0.36 & & 0.80 \\
\hline Lives on the street $(1=$ yes $)$ & & & & & & & & & 0.36 & 0.57 & & 1.44 & 0.48 & 0.59 & & 1.62 \\
\hline Displaced child ( 1 = yes) & & & & & & & & & -0.59 & 0.32 & $<0.10$ & 0.55 & -0.52 & 0.34 & & 0.59 \\
\hline Health care coverage & & & & & & & & & & & & & & & & \\
\hline$(1=$ yes $)$ & & & & & & & & & & & & & 0.34 & 0.37 & & 1.40 \\
\hline Lima & & & & & & & & & & & & & NA & & & \\
\hline Bogotá & & & & & & & & & & & & & -0.29 & 0.44 & & 0.75 \\
\hline Quito & & & & & & & & & & & & & 0.88 & 0.51 & $<0.10$ & 2.42 \\
\hline São Paulo & & & & & & & & & & & & & 0.68 & 0.54 & & 1.98 \\
\hline
\end{tabular}

tions of Latin America and to examine occupational and sociodemographic factors that predict the incidence and severity of work-related injuries.

Notably, the mean age of child street laborers in this study was 11.8 years. Children were working in numerous occupations, including selling, cleaning/ guarding cars, begging, and performing, in spite of ILO conventions setting the minimum age of employment at 15 years, and prohibiting hazardous employment of children less than 18 years (2). Two-thirds of the child street laborers were male, an outcome consistent with other Latin American studies revealing that among street children, boys work more often than girls $(41,42,45)$. As in previous research documenting street children's limited access to health care $(41,42,45)$, only $37.0 \%$ of the study children reported having any healthrelated coverage. Two-thirds $(64.9 \%)$ of the group reported being forced or displaced from their area of origin, supporting the relationship between displacement and the working street-child found in previous research on Latin American children (6).

Comparing older children to younger children revealed some differences in the nature of street labor and life cir- cumstances. Younger children were more likely to work as beggars, to attend school, to have been displaced, to have health care coverage, and to be working in Bogotá or São Paulo. Older children were more likely to work in other occupations and to live in Lima. It is likely that younger children were more effective beggars and that older children had the skills to engage in other work, including illegal activities (42). School attendance was higher for younger children, supporting the argument that child labor contributes to school dropout (1, 11). Younger children were more likely to be displaced than their older peers, a finding consistent with prior research on the displaced population and highlighting the vulnerability of this group of young street laborers (6). Finally, older children were less likely than younger children to have health care coverage, a finding likely attributed to diminished family contact (42).

The incidence of occupational injury for the sample of 584 children working in the targeted cities was $39.6 \%$. This figure is well above the incidence of child occupational injury found in existing literature-ranging from $3.3 \%-17.0 \%$ in samples from the US and Latin America $(17,18,21)$. This disparity may be ex- plained, in part, by the fact that some previous studies focused on annual (versus lifetime) incidence of occupational injury and used adult respondents to report on child injuries $(17,18)$. Yet despite these methodological discrepancies, a $39.6 \%$ lifetime rate of occupational injury indicates that working in the streets can be very dangerous for children. The relatively high incidence of serious injuries, such as burns (8.6\%), car accidents $(8.9 \%)$, and amputations $(0.3 \%)$, emphasizes the hazards of street work for child health, safety, and emotional stability.

The scratches and cuts/lacerations that were the most common occupational injuries suffered by the study children were debilitating enough to prevent working for at least one day. Such injuries have previously been linked to contact with cars, fights with other workers, and altercations with the police (45-47). Children's risk of these injuries was exacerbated by the prevalence of broken glass, car parts, knives, and sharp objects in the streets of the target cities $(46,47)$.

Child street laborers reported working an average of 46 hours weekly, including approximately 39 daytime hours and 7 nighttime hours. This average exceeds the conventional adult work week, but is 
consistent with national surveys of developing countries that have found that more than one-third of children 5-14 years work more than 40 hours per week (1). Interestingly, two-thirds of the children in this study reported attending school, a percentage higher than the onethird to one-half of street children enrolled in school in previous studies (41, $42,45)$. However, given that children were interviewed on school days when they should have been in class or studying, it is reasonable to conclude that street work contributes to absenteeism, fatigue, and compromised school performance. Previous research has found that child laborers are more likely than nonworking children to fail in school (48).

An examination of predictors of any occupational injury revealed that the number of hours of daytime work, type of occupation, age of child, and minority status were significantly associated with higher risk; specifically, older children, non-minority children, children working more daytime hours, and children who performed were more likely to have experienced an occupational injury. Since this study measured lifetime incidence of occupational injury, it was not surprising that older children had a greater likelihood of injury. Contrary to previous research (24-26), non-minority children (white/mestizo) were more likely to report an injury than black/native children. This finding may be attributable to higher levels of adult supervision of minority children who are often in the streets with their displaced families (6). Alternatively, minority children may have been more street savvy than their non-minority peers.

As in previous studies $(23,27)$, longer hours of daytime work predicted a higher incidence of occupational injuries, likely influenced by exhaustion and immature biological systems. Current findings expand the literature by revealing that children who are performing street acts have three times the injury rate of those engaged in selling; these children are more likely than their peers to engage in unprotected acrobatics, to work with knives and dangerous objects, and to have contact with flammable and combustible substances.

A child's gender was the only significant predictor of moderate-to-severe occupational injuries. As in prior studies $(15,17,20,23)$, boys were more likely than girls to report a serious injury, a finding that may be linked to male "machismo," or boys' greater willingness to do dangerous work.

The trend for older age to be associated with a greater likelihood of serious injury might be explained by the additional time spent in the workforce, or a willingness to take on more hazardous work as age increases.

The trend for a higher incidence of moderate-to-severe injuries in Quito as compared to the other target cities was surprising. However this finding may be due to a high level of traffic problems and automobile/pedestrian accidents in the downtown area.

\section{Limitations and future research}

The current findings expand the literature on child occupational injuries in Latin America. However, the following limitations must be noted. First, the research was cross-sectional, so no causal directions should be inferred from detected relationships. Second, the children's participation was voluntary, making the sample neither random nor entirely representative of child street laborers in the target cities. Notably, all interviews were conducted during daytime hours, so children working exclusively in the evenings were not included. It is likely that a lack of light would further jeopardize safety and security, contributing to even greater risk of occupational injury for those children. Third, this study was limited to four major cities, so findings cannot be generalized to child laborers throughout Latin America.

Other limitations included the narrow focus of survey items and the possibility of response bias. The study addressed only physical occupational injuries, omitting work-related mental health problems that are also prevalent among this group of children $(39,46,49)$. Children reported their injuries retrospectively so they may not have recalled their injuries accurately. Moreover, some children may have under-reported their injuries, especially those that were more severe, because they wanted to appear as competent as adult workers (35). Unfortunately, it was impossible to independently establish the reliability of children's responses through medical records or other data sources.

To address these limitations, future research is needed that will further exam- ine the conditions of children working in the streets of Latin America, the nature of their work-related injuries, and the impact of these injuries on child development, education, and other life outcomes. Future studies should employ longitudinal methods, include nighttime workers, use multiple measures of childhood injuries (child and parent/adult reports, medical/hospital records), and add measures of work-related mental health outcomes (e.g., stress, depression). Studies should survey children in other Latin American cities, and in different areas of cities, since injuries may vary as a function of geographic niche. Future research should explore not only the correlates and causes of occupational injuries, but also the potential protective factors (e.g., adult supervision, hours in school), using more complex models to identify possible moderating and mediating influences. These studies might also explore whether patterns of protective processes differ between boys and girls and for children at different developmental stages.

\section{Programmatic and policy implications}

Despite its limitations, this study has implications for programs and policies designed to reduce the prevalence and severity of occupational injuries among working street-children in the cities of Latin America. The $39.6 \%$ rate of "at least one lifetime occupational injury" combined with the high incidence of serious injuries, such as burns, car accidents, and amputations, warrants interventions to improve child safety and well-being. Given the significant relationship between child work hours and the incidence of occupational injury, it is especially important to change parent/ caregiver attitudes about the benefits of early work $(35,49)$ and to educate adults about the risks of work-related injuries. While not all work is bad, educators and practitioners should help parents / caregivers understand the benefits of schooling, consistent attendance, and regular study time to improving every child's life outcome; early work should not compromise education, recreation, or rest. Moreover, given the importance of family and social networks in Latin American culture, practitioners should communicate the risks of child labor to the extended family and other adults who have regular contact with children. 
The current findings underscore the need for immediate improvements in the conditions impacting child street-laborers in the targeted cities. In particular, there is a need to reduce long daytime work hours, ban child street-performances, and reduce boys' vulnerability to more serious injuries. The heightened risk of moderate-to-severe injuries in Quito indicates a need to develop interventions that target hazards of unique urban environments. Such interventions will require the collaboration of multiple sectors-local governments, schools, health and social service providers, courts, churches, and development agencies-to protect children from the dangers of street labor and to ensure that such labor does not block their access to education.

Since health promotion and prevention efforts may reduce, but not eliminate, child street labor, it is also important that schools and community agencies introduce safety training and skill-building programs for child work- ers. These programs should attempt to increase children's knowledge of occupational injuries, reduce their hours of work and involvement in performing activities, and provide safety training for working in the presence of cars/traffic, unsanitary conditions, pollution, high noise levels, poverty, and other urban stressors. Efforts should also be made to increase child access to health care, so that adequate care is available for occupational injuries.

In addition to these more immediate interventions, governments and community stakeholders should make efforts to combat the causes of inappropriate child labor, including the shortage of good schools and day care, lack of social and health care services, and limited occupational choices for women/mothers (50). Many parents, especially mothers of child laborers, are unemployed or underemployed, and rely on their children's income. Moreover, the poor quality of education in some areas acts as a disincentive to school attendance (50). Thus, child/family advocates must encourage quality education that teaches children skills for employment; health and social services that help families survive crises (e.g., displacement, disease, loss of shelter); increases in family income; and better access to employment/economic opportunities for women (48). With a combination of multilevel policies and culturally-sensitive interventions, the countries of Latin America can reduce child street labor and occupational injuries, as well as raise the level of education and job preparedness of future generations.

Acknowledgements. We wish to acknowledge and thank the children who answered the questionnaire and their families, the interviewers and medical students who provided assistance, and Milciades Ibañez and Juan Carlos Botero who provided advice at various stages of the project.

\section{REFERENCES}

1. Hagemann F, Diallo Y, Etienne A, Mehran F. Global child labour trends 2000 to 2004. Geneva, Switzerland: International Labour Organization-SIMPOC; 2006.

2. Minimum Age Convention C-138. Governing Body of the International Labor Office. 1973; 58 (06/19/1976). Available from: http:// www.ilo.org/ilolex/english/convdisp1.htm. Accessed 14 June 2009.

3. Worst Forms of Child Labour Convention C-182. Governing Body of the International Labour Office. 1999;87 (11/19/2000). Available from: http://www.ilo.org/ilolex/english/ convdisp1.htm. Accessed 14 June 2009.

4. UNICEF. The state of the world's children 2006: excluded and invisible. UNICEF; 2005. (11112006).

5. Pick W, Ross M, Dada Y. The reproductive and occupational health of women street vendors in Johannesburg, South Africa. Soc Sci Med. 2002;54(2) (Jan):193-204.

6. Pinzon-Rondon A, Hofferth S, Briceno L. Children working in the streets of Colombian cities: Different pathways to the street lead to different populations. Child Youth Serv Rev. 2008;30(12):1417-24

7. Varillas W. The hazardous child labor network (Red Tip). Lima, Peru: IPEC/OIT; 2004.

8. Salminen $\mathrm{S}$. Have young workers more injuries than older ones? An international literature review. J Safety Res. 2004;35(5):513-21.

9. Breslin F, Smith P. Age-related differences in work injuries: a multivariate, populationbased study. Am J Ind Med. 2005;48(1) (Jul): 50-6.

10. Center for Disease Control and Prevention. Nonfatal occupational injuries and illnesses treated in hospital emergency departments United States, 1998. JAMA. 2001;285(May): 2443-4.

11. Briceño-Ayala L, Pinzon-Rondon A. Effects of child labor upon the health of the child worker. Rev Salud Publica (Bogota). 2004;6 (Sep-Dec):270-88.

12. Breslin C, Polzer J, MacEachen E, Morrongiello B, Shannon H. Workplace injury or "part of the job"?: Towards a gendered understanding of injuries and complaints among young workers. Soc Sci Med. 2007;64:782-93.

13. International Labor Organization. Recording and notification of occupational accidents and diseases. Geneva: ILO; 1996.

14. Breslin C, Koehoorn M, Smith P, Manno M. Age related differences in work injuries and permanent impairment: a comparison of workers' compensation claims among adolescents, young adults, and adults. Occup Environ Med. 2003;60(9):E10.

15. Frone M. Predictors of work injuries among employed adolescents. J Appl Psychol. 1998; 83(4):565-76.

16. Baron SL. Injuries in child laborers. Public Health Rep. 2005;120(Nov-Dec):598-601.

17. Santana V, Itaparica M, Amorim A, Araujo J, Oliveira M, Cooper S. Non-fatal work-related injuries in adolescents. Cad. Saude Publica. 2003;19(2):407-20.

18. Cordeiro R, Chiodi Prestes S, Grotti Clemente A, Segre Clemente C, Sakate M, Donalisio M. Incidence of non-fatal work-related accidents in Southeast Brazil. Cad Saude Publica. 2006; 22(2):387-93.

19. Brooks D, Davis L, Gallagher S. Work-related injuries among Massachusetts children: a study based on emergency department data. Am J Ind Med. 1993;24(3):313-24.

20. Miller M, Kaufman J. Occupational injuries among adolescents in Washington State, 1988-1991. Am J Ind Med. 1998;34(2):121-32.

21. Parker D, Carl W, French L, Martin F. Nature and incidence of self-reported adolescent work injury in Minnesota. Am J Ind Med. 1994;26(4) (Oct):529-41.

22. Noe R, Rocha J, Clavel-Arcas C, Aleman C, Gonzales M, Mock C. Occupational injuries identified by an emergency. Inj Prev. 2004;10: 227-32.

23. Zierold K, Garman S, Anderson H. Summer work and injury among middle school students, aged 10-14 years. Occup Environ Med. 2004;61:518-22.

24. Breslin F, Day D, Tompa E et al. Nonagricultural work injuries among youth: a systematic review. Am J Prev Med. 2007;32(2): 151-62.

25. Goldcamp E, Hendricks K, Layne L, Myers J. Nonfatal injuries to household youth on racial minority-operated farms in the US, 2000. J Agric Saf Health. 2006;12(4):315-24.

26. Zierold K, Anderson H. Racial and ethnic disparities in work-related injuries among teenagers. J Adolesc Health. 2006;39(3):422-26.

27. Brooks D, Davis L. Work-related injuries to Massachusetts teens, 1987-1990. Am J Ind Med. 1996;29(2):153-60.

28. Forastieri V. Children at work: health and safety risks. Geneva: International Labour Office; 1997.

29. Marlenga B, Brison R, Berg R, Zentner J, Linneman J, Pickett W. Evaluation of the North American Guidelines for Children's Agricul- 
tural Tasks using a case series of injuries. Inj Prev. 2004;10:350-7.

30. White L, O'Donell C. Working children and accidents: Understanding the risks. Child Care Health Dev. 2001;27(1):23-34.

31. Banco L, Lapidus G, Braddock M. Workrelated injury among Connecticut minors. Pediatrics. 1992;89(5 Pt 1) (May):957-60.

32. Perry M, May J. Noise and chemical induced hearing loss: special considerations for farm youth. J Agromedicine. 2005;10(2):49-55.

33. Bartels S, Niederman B, Waters T. Job hazards for musculoskeletal disorders for youth working on farms. J Agric Saf Health. 2000;6(3): 191-201.

34. Breslin F, Smith P, Dunn J. An ecological study of regional variation in work injuries among young workers. BMC Public Health. 2007;23(7):91.

35. Casa Alianza. Trabajo infantil: Visión de conjunto. Mexico; 2003. (05032004).

36. Szaniszlo J, Ungvary G. Polycyclic aromatic hydrocarbon exposure and burden of outdoor workers in Budapest. J Toxicol Environ Health. 2001;62(5):297-306.

37. Duarte-Davidson R, Courage C, Rushton L, Levy L. Benzene in the environment: an assessment of the potential risks to the health of the population. Occup Environ Med. 2001; 58(1):2-13.
38. Thomas P, Zelikoff J. Air pollutants: Modulators of pulmonary host resistance against infections. New York: Academic Press; 1999

39. Power C, Stansfeld S, Matthews S, Manor O, Hope S. Childhood and adulthood risk factors for socio-economic differentials in psychological distress: evidence from the 1958 British birth cohort. Soc Sci Med. 2002;55(11) 1989-2004.

40. Hernández-Pena P, Kageyama M, Coria I, Hernández B, Harlow S. Condiciones de trabajo, fatiga laboral y bajo peso al nacer entre vendedores ambulantes. Salud Publica Mex. 1999;41(2) (Mar-Apr):101-9.

41. Quintero H, Rivas W. El Salvador trabajo infantil urbano: una evaluación rápida. Geneva: OIT; 2002.

42. Pinzon-Rondon A, Briceno-Ayala L, Botero J Cabrera P, Rodriguez M. Trabajo infantil ambulante en las capitales latinoamericanas. Salud Pública Méx. 2006;48(5):363-72.

43. World Bank. Regional Fact Sheet from the World Development Indicators 2007. Washington, DC: World Bank; 2007.

44. Pinzon A, Briceño L, Gomez A, Latorre C. Trabajo infantil en las calles de Bogotá. Revista Ciencias de la Salud. 2003;1(2):151-63.

45. Laniado-Laborin R, Moreno C, Vargas R, Deosaransingh K, Woodruff S, Sallis J. Los niños que trabajan en las calles de Tijuana. Perfil epidemiológico y prevalencia de experimentación con tabaco. Salud Publica Mex. 1995; 37(2):149-54.

46. UNICEF Colombia, Universidad Nacional de Colombia. Creciendo en el Asfalto. Niños, Niñas y Jóvenes Vendedores en las Calles de Bogotá. Bogotá DC (Colombia): Universidad Nacional de Colombia; 2002.

47. Cárdenas S, Rivera N, Boteman J, Aguirre P. Renacer una propuesta para volver a nacer. Bogotá, Colombia: Agora Editores Ltda; 2000.

48. UNICEF. The state of the world's children 2007. New York, NY: UNICEF; 2006.

49. Salazar MC. Niños y jóvenes trabajadores buscando un futuro mejor. Bogotá, Colombia: Centro editorial Universidad Nacional de Colombia-UNICEF; 1990.

50. Boyden J, Ling B, Myers W. What works for working children. Stockholm: Radda Barnen; 1998.

Manuscript received on 6 September 2008. Revised version accepted for publication on 15 March 2009.

RESUMEN Objetivos. Determinar la prevalencia y la naturaleza de las lesiones laborales en niños que trabajan en las calles de cuatro grandes ciudades de América Latina e identificar los factores de predicción de esas lesiones.

Lesiones laborales en niños que trabajan en la calle en América Latina: prevalencia y factores de predicción

Palabras clave
Métodos. Estudio transversal mediante entrevistas a 584 niños de 5 a 17 años que trabajaban en las calles de Bogotá, Colombia; Lima, Perú; Quito, Ecuador; y São Paulo, Brasil. Se realizaron análisis descriptivos y regresiones logísticas multifactoriales de la incidencia y la gravedad de las lesiones con relación a las variables laborales y sociodemográficas.

Resultados. Aproximadamente 39,6\% de los niños trabajadores de la calle encuestados informó haber sufrido lesiones mientras trabajaba: rasguños $(19,5 \%)$, heridas/laceraciones $(16,4 \%)$, quemaduras $(8,6 \%)$, accidentes con automóviles $(8,9 \%)$, esguinces $(4,6 \%)$ y amputaciones $(0,3 \%)$. Los factores de predicción de mayor riesgo de lesiones fueron trabajar en la calle muchas horas diurnas y realizar presentaciones callejeras, incluso después de controlar por factores sociodemográficos; específicamente, la adición de una hora de trabajo diurno aumentó el riesgo de lesión en 1,4\%. Los niños que realizaban presentaciones callejeras presentaron una tasa de lesiones tres veces mayor que los niños que se dedicaban fundamentalmente a la venta de productos. Los niños varones, los de mayor edad y los de Quito presentaron mayor probabilidad de sufrir lesiones de moderadas a severas que las niñas, los más jóvenes y los que vivían en las otras ciudades estudiadas.

Conclusiones. Se requieren intervenciones para reducir el considerable riesgo de lesiones a que están sometidos los niños que trabajan en las calles de las ciudades de América Latina.

Trabajo de menores; jóvenes sin hogar; accidentes de trabajo; Brasil; Colombia; Ecuador; Perú; América Latina. 